\title{
Omvang risicogroepen in de Limburgse gemeente Beek
}

Citation for published version (APA):

Künn, A., \& Poulissen, D. (2019). Omvang risicogroepen in de Limburgse gemeente Beek. ROA. ROA Fact Sheets No. 003-6191 https://doi.org/10.26481/umarof.2019003-6191

Document status and date:

Published: 27/03/2019

DOI:

10.26481/umarof.2019003-6191

Document Version:

Publisher's PDF, also known as Version of record

\section{Please check the document version of this publication:}

- A submitted manuscript is the version of the article upon submission and before peer-review. There can be important differences between the submitted version and the official published version of record.

People interested in the research are advised to contact the author for the final version of the publication, or visit the DOI to the publisher's website.

- The final author version and the galley proof are versions of the publication after peer review.

- The final published version features the final layout of the paper including the volume, issue and page numbers.

Link to publication

\footnotetext{
General rights rights.

- You may freely distribute the URL identifying the publication in the public portal. please follow below link for the End User Agreement:

www.umlib.nl/taverne-license

Take down policy

If you believe that this document breaches copyright please contact us at:

repository@maastrichtuniversity.nl

providing details and we will investigate your claim.
}

Copyright and moral rights for the publications made accessible in the public portal are retained by the authors and/or other copyright owners and it is a condition of accessing publications that users recognise and abide by the legal requirements associated with these

- Users may download and print one copy of any publication from the public portal for the purpose of private study or research.

- You may not further distribute the material or use it for any profit-making activity or commercial gain

If the publication is distributed under the terms of Article $25 \mathrm{fa}$ of the Dutch Copyright Act, indicated by the "Taverne" license above, 
Maastricht University $\$$ ROA

\section{Omvang risicogroepen in de Limburgse gemeente Beek}

Annemarie Künn

Davey Poulissen

\section{ROA Factsheet}

ROA-F-2019/3 - Beek

Researchcentrum voor Onderwijs en Arbeidsmarkt | ROA Research Centre For Education and the Labour Market / ROA 


\section{Omvang risicogroepen in de Limburgse gemeente}

Beek

\section{Snelle feiten en cijfers ${ }^{1}$}

1. Ongeveer $19,6 \%$ van de 15 tot en met 67-jarige inwoners van de gemeente Beek bevindt zich in een risicopositie omdat zij een arbeidsongeschiktheids-, werkloosheids- of bijstandsuitkering ontvangen, of omdat zij inactief zijn op de arbeidsmarkt.

2. Het percentage personen dat zich in een risicopositie bevindt, is binnen de gemeente Beek het hoogst in de wijk Beek-Spaubeek (20\%).

\section{Inleiding}

In december 2018 is een factsheet gepubliceerd waarin de omvang van de risicogroepen in Limburg in kaart is gebracht op peildatum 31 december $2015 .^{2}$ Voortbouwend op deze zogenaamde nulmeting, bekijken we in deze factsheet de situatie in de gemeente Beek op 31 december 2017. De gemeente Beek telde op 31 december 2017, 10.594 inwoners die tot de potentiële beroepsbevolking behoorden én op 31 december 2015 reeds in Nederland woonachtig waren. ${ }^{3}$ Dat wil zeggen dat zij, gezien hun leeftijd, in principe actief zouden kunnen zijn op de arbeidsmarkt. ${ }^{4}$ Een deel van deze inwoners bevindt zich echter in een risicopositie omdat zij uitkeringsafhankelijk en/of niet actief op de arbeidsmarkt zijn. Daardoor is hun financiële positie vaak ook zwak en lopen ze op termijn een groter risico op langdurige uitkeringsafhankelijkheid en maatschappelijke uitsluiting.

In deze factsheet maken we voor de gemeente Beek inzichtelijk wat de absolute en relatieve omvang is van

1 Tot de gemeente Beek behoren (in 2017) de volgende wijken: Beek-Spaubeek en Beek-Zuid.

2 Zie: ROA (2018) Omvang risicogroepen in Limburg, ROA-F2018/20.

3 Mensen die tussen 31 december 2015 en 31 december 2017 geïmmigreerd zijn vallen dus buiten het bereik van deze factsheet. Deze toevoeging wordt in de rest van de factsheet niet herhaald.

4 De potentiële beroepsbevolking wordt door ons gedefinieerd als alle inwoners in de leeftijd 15 tot en met 67 jaar. een viertal groepen inwoners met een risicopositie, namelijk:

1. Personen met een arbeidsongeschiktheidsuitkering

2. Personen met een werkloosheidsuitkering

3. Personen met een bijstandsuitkering

4. Personen die inactief zijn zonder dat zij onderwijs volgen of één of meerdere van de hierboven genoemde uitkeringen ontvangen. Personen die de AOW-gerechtigde leeftijd hebben bereikt of een pensioenuitkering ontvangen worden niet als inactief bestempeld.

Omdat het mogelijk is dat inwoners naast het ontvangen van de drie genoemde uitkeringstypes werken, brengen we tevens in kaart welk deel van de uitkeringsafhankelijken naast hun uitkering betaald werk verricht. Personen die naast het ontvangen van een uitkering betaald werk verrichten lopen om allerhande redenen minder risico. Allereerst wordt hun uitkering aangevuld door inkomen uit werk, waardoor hun financiële positie over het algemeen beter zal zijn dan zonder deze inkomsten. Daarnaast kan het feit dat zij actief zijn op de arbeidsmarkt het risico op maatschappelijke uitsluiting verkleinen. Tot slot kan het feit dat zij betaald werk verrichten het risico op langdurige uitkeringsafhankelijkheid verminderen.

Om de cijfers voor de gemeente Beek in context te plaatsen, vergelijken we deze met cijfers voor de provincie Limburg als geheel, de verschillende COROP-regio's (Noord-, Midden- en Zuid-Limburg) en Nederland als geheel. Deze factsheet geeft daarmee de omvang van de verschillende risicogroepen in de gemeente Beek weer en vergelijkt deze met de genoemde referentieregio's. Dit is een belangrijke eerste stap alvorens bekeken kan worden wat de specifieke (en complexe) problematiek is van de mensen die tot deze risicogroepen behoren en in hoeverre re-integratiebeleid uitstroom uit een risicosituatie kan stimuleren. 


\section{Factsheet}

ROA-F-2019/3 - Beek

\section{Inwoners met een arbeidsongeschiktheidsuitkering}

TABEL1.

Overzicht van de absolute en relatieve omvang van inwoners met een arbeidsongeschiktheidsuitkering (AO-uitkering)

\begin{tabular}{|c|c|c|c|c|}
\hline & $\begin{array}{r}\text { Aantal inwoners met een } \\
\text { A0-uitkering }\end{array}$ & $\begin{array}{l}\text { Aantal inwoners behorend tot de } \\
\text { potentiële beroepsbevolking }\end{array}$ & $\begin{array}{r}\text { Percentage inwoners met een } \\
\text { A0-uitkering }\end{array}$ & $\begin{array}{l}\text { Percentage werkende onder } \\
\text { inwoners met een } \mathrm{A} 0 \text {-uitkering }\end{array}$ \\
\hline Gemeente Beek & 823 & 10.594 & $7,8 \%$ & $18,5 \%$ \\
\hline Noord-Limburg & 12.364 & 187.721 & $6,6 \%$ & $20,6 \%$ \\
\hline Midden-Limburg & 12.629 & 157.217 & $8 \%$ & $17,7 \%$ \\
\hline Zuid-Limburg & 39.810 & 395.604 & $10,1 \%$ & $15 \%$ \\
\hline Limburg totaal & 64.803 & 740.542 & $8,8 \%$ & $16,6 \%$ \\
\hline Nederland totaal & 727.889 & 11.460 .361 & $6,4 \%$ & $17,9 \%$ \\
\hline
\end{tabular}

Bron: ROA, berekeningen op basis van microdata van het CBS

Tabel 1 geeft een overzicht van de omvang van het aantal personen met een arbeidsongeschiktheidsuitkering in de gemeente Beek. Om de cijfers voor Beek in context te plaatsen worden ze ook vergeleken met de cijfers voor de provincie Limburg als geheel en de drie onderliggende COROP-regio's Noord-, Midden- en Zuid-Limburg.

Uit Tabel 1 zijn een aantal conclusies te trekken:

- De gemeente Beek telde op 31 december 2017, 823 inwoners met een arbeidsongeschiktheidsuitkering, oftewel 7,8 procent van het aantal inwoners dat tot de potentiële beroepsbevolking behoort.

- Dit percentage is lager dan het percentage in de bijbehorende COROP-regio Zuid-Limburg (10,1\%), maar min of meer gelijk aan het percentage voor de provincie Limburg als geheel (8,8\%).

- Terwijl het percentage inwoners met een arbeidsongeschiktheidsuitkering in de provincie Limburg hoger is dan voor Nederland als geheel $(6,4 \%)$, is het percentage in de gemeente Beek min of meer gelijk aan dat voor Nederland als geheel.

- Van de inwoners met een arbeidsongeschiktheidsuitkering, woonachtig in de gemeente Beek, werkt 18,5 procent. Dit is hoger dan het percentage in de COROP-regio Zuid-Limburg (15\%), hoger dan het percentage voor Limburg als geheel $(16,6 \%)$ en min of meer gelijk aan het landelijk percentage $(17,9 \%)$.
Figuur 1 geeft voor iedere Limburgse gemeente het percentage inwoners weer dat een arbeidsongeschiktheidsuitkering ontvangt.

Uit Figuur 1 valt het volgende af te leiden:

- Het percentage inwoners met een arbeidsongeschiktheidsuitkering verschilt aanzienlijk tussen de Limburgse gemeentes.

- De gemeente Beek staat op de 15e plek in Limburg wat betreft het percentage inwoners met een arbeidsongeschiktheidsuitkering (gesorteerd van laag naar hoog).

Figuur 2 geeft de spreiding binnen de gemeente Beek weer in het percentage inwoners met een arbeidsongeschiktheidsuitkering.

Op basis van Figuur 2 kunnen we de volgende conclusies trekken:

- In de wijk Beek-Spaubeek is het percentage mensen met een arbeidsongeschiktheidsuitkering 7,9 procent.

- In de wij Beek-Zuid is het percentage mensen met een arbeidsongeschiktheidsuitkering 6,6 procent. 


\section{Omvang risicogroepen in de Limburgse gemeente}

Beek

FIGUUR 1.

Percentage inwoners met een arbeidsongeschiktheidsuitkering naar Limburgse gemeente

$14 \%$

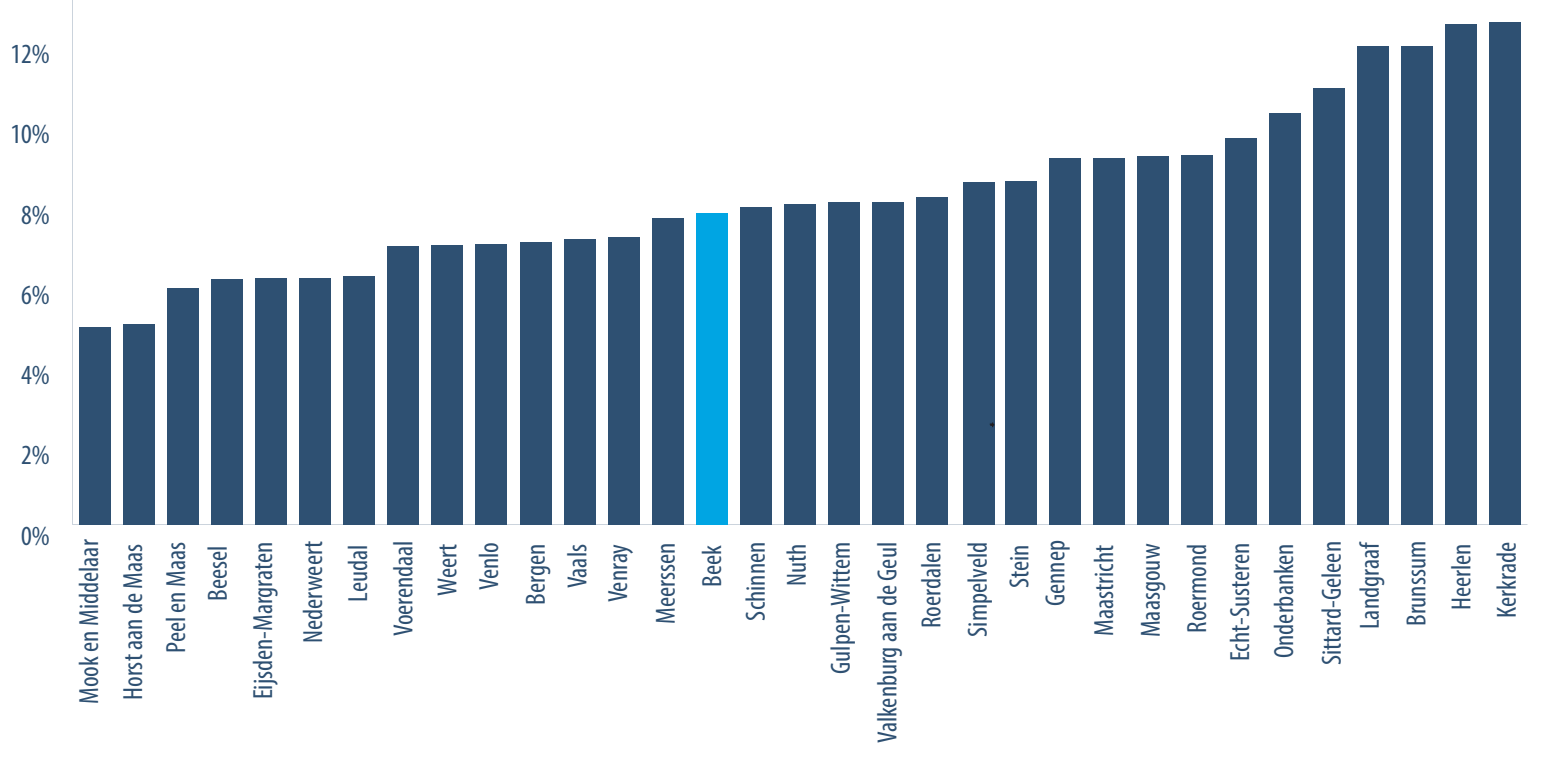

Bron: ROA, berekeningen op basis van microdata van het CBS

FIGUUR 2.

Percentage inwoners met een arbeidsongeschiktheidsuitkering naar wijk

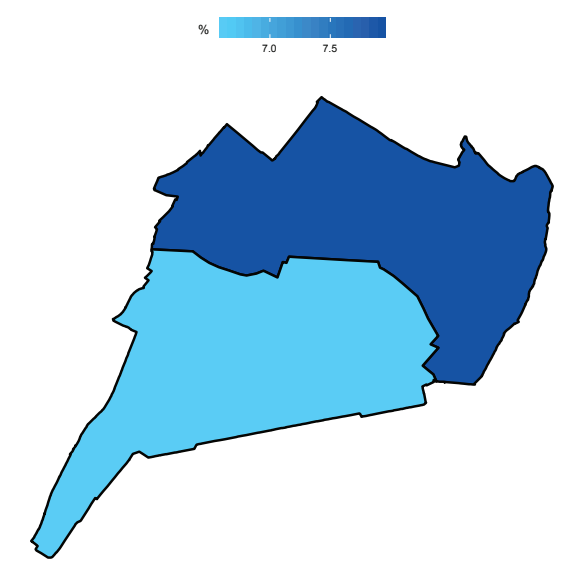

Bronnen: ROA, berekeningen op basis van microdata van het CBS; Kadaster/CBS, Wijk- en buurtkaart 2017 


\section{Factsheet}

ROA-F-2019/3 - Beek

\section{Inwoners met een werkloosheidsuitkering}

TABEL 2.

Overzicht van de absolute en relatieve omvang van inwoners met een werkloosheidsuitkering (WW-uitkering)

\begin{tabular}{|l|r|r|r|r|} 
& $\begin{array}{r}\text { Aantal inwoners met een } \\
\text { WW-uitkering }\end{array}$ & $\begin{array}{r}\text { Aantal inwoners behorend } \\
\text { tot de potentiele } \\
\text { beroepsbevolking }\end{array}$ & $\begin{array}{r}\text { Percentage inwoners met een WW- } \\
\text { uitkering }\end{array}$ & $\begin{array}{r}\text { Percentage werkenden onder inwoners } \\
\text { met een WW-uitkering }\end{array}$ \\
\hline Gemeente Beek & 239 & 10.594 & $2,3 \%$ & $54,4 \%$ \\
\hline Noord-Limburg & 5.469 & 187.721 & $2,9 \%$ & $50,6 \%$ \\
\hline Midden-Limburg & 3.826 & 157.217 & $2,4 \%$ & $51 \%$ \\
\hline Zuid-Limburg & 9.291 & 395.604 & $2,3 \%$ & $51,3 \%$ \\
\hline Limburg totaal & 18.586 & 740.542 & $2,5 \%$ & $51 \%$ \\
\hline Nederland totaal & 287.189 & 11.460 .361 & $2,5 \%$ & $47,6 \%$ \\
\hline
\end{tabular}

Bron: ROA, berekeningen op basis van microdata van het CBS

Tabel 2 geeft een overzicht van de omvang van het aantal personen met een werkloosheidsuitkering in de gemeente Beek. Ook hier worden de cijfers voor Beek in context geplaatst door ze te vergelijken met de cijfers voor de provincie Limburg als geheel en de drie onderliggende COROP-regio's Noord-, Midden- en ZuidLimburg.

Uit Tabel 2 zijn een aantal conclusies te trekken:

- De gemeente Beek telde op 31 december 2017, 239 inwoners met een werkloosheidsuitkering, oftewel 2,3 procent van het aantal inwoners dat tot de potentiële beroepsbevolking behoort.

- Dit percentage is gelijk aan het percentage in de bijbehorende COROP-regio Zuid-Limburg (2,3\%) en min of meer gelijk aan het percentage voor de provincie Limburg als geheel $(2,5 \%)$.

- Zowel in de gemeente Beek als in de provincie Limburg als geheel is het percentage inwoners met een werkloosheidsuitkering min of meer gelijk aan het landelijk gemiddelde (2,5\%).

- Van de inwoners met een werkloosheidsuitkering, woonachtig in de gemeente Beek, werkt 54,4 procent. Dit is hoger dan het percentage in de COROP-regio Zuid-Limburg (51,3\%), hoger dan het percentage voor Limburg als geheel (51\%) en hoger dan het landelijk percentage $(47,6 \%)$.
Figuur 3 geeft voor iedere Limburgse gemeente het percentage inwoners weer dat een werkloosheidsuitkering ontvangt.

Uit Figuur 3 valt het volgende af te leiden:

- Het percentage inwoners met een werkloosheidsuitkering verschilt in beperkte mate tussen de Limburgse gemeentes.

- De gemeente Beek staat op de $9^{\text {e }}$ plek in Limburg wat betreft het percentage inwoners met een werkloosheidsuitkering (gesorteerd van laag naar hoog).

Figuur 4 geeft de spreiding binnen de gemeente Beek weer in het percentage inwoners met een werkloosheidsuitkering.

Op basis van Figuur 4 kunnen we de volgende conclusies trekken:

- In de wijk Beek-Spaubeek is het percentage mensen met een werkloosheidsuitkering 2,3 procent.

- In de wijk Beek-Zuid is het percentage mensen met een werkloosheidsuitkering 2 procent. 


\section{Omvang risicogroepen in de Limburgse gemeente}

Beek

FIGUUR 3.

Percentage inwoners met een werkloosheidsuitkering naar Limburgse gemeente

$4 \%$

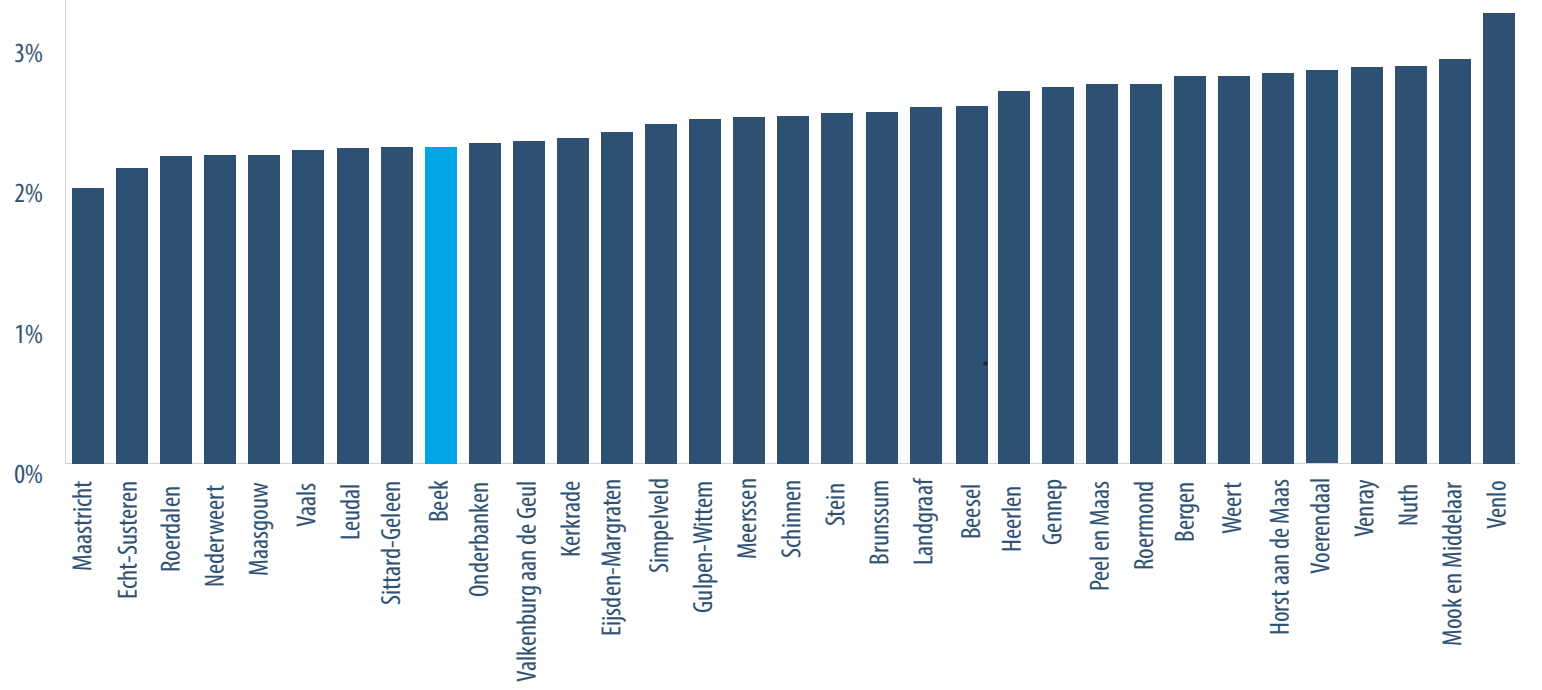

Bron: ROA, berekeningen op basis van microdata van het CBS

FIGUUR 4.

Percentage inwoners met een werkloosheidsuitkering naar wijk

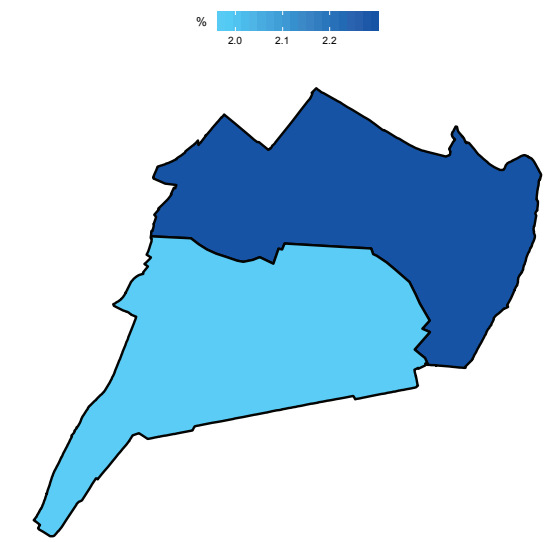

Bronnen: ROA, berekeningen op basis van microdata van het CBS; Kadaster/CBS, Wijk- en buurtkaart 2017 


\section{Factsheet}

ROA-F-2019/3 - Beek

\section{Inwoners met een bijstandsuitkering}

TABEL 3.

Overzicht van de absolute en relatieve omvang van inwoners met een bijstandsuitkering

\begin{tabular}{|c|c|c|c|c|}
\hline & $\begin{array}{r}\text { Aantal inwoners met een } \\
\text { bijstandsuitkering }\end{array}$ & $\begin{array}{r}\text { Aantal inwoners } \\
\text { behorend tot } \\
\text { de potentiële } \\
\text { beroepsbevolking }\end{array}$ & $\begin{array}{r}\text { Percentage inwoners met een } \\
\text { bijstandsuitkering }\end{array}$ & $\begin{array}{l}\text { Percentage werkenden onder inwoners met } \\
\text { een bijstandsuitkering }\end{array}$ \\
\hline Gemeente Beek & 314 & 10.594 & $3 \%$ & $11,1 \%$ \\
\hline Noord-Limburg & 6.296 & 187.721 & $3,4 \%$ & $13,3 \%$ \\
\hline Midden-Limburg & 4.873 & 157.217 & $3,1 \%$ & $12,2 \%$ \\
\hline Zuid-Limburg & 19.344 & 395.604 & $4,9 \%$ & $8,9 \%$ \\
\hline Limburg totaal & 30.513 & 740.542 & $4,1 \%$ & $10,3 \%$ \\
\hline Nederland totaal & 479.069 & 11.460 .361 & $4,2 \%$ & $11,1 \%$ \\
\hline
\end{tabular}

Bron: ROA, berekeningen op basis van microdata van het CBS

Tabel 3 geeft een overzicht van de omvang van het aantal personen met een bijstandsuitkering in de gemeente Beek. Om de cijfers voor Beek in context te plaatsen worden ze wederom vergeleken met de cijfers voor de provincie Limburg als geheel en de drie onderliggende COROP-gebieden Noord-, Midden- en Zuid-Limburg.

Uit Tabel 3 zijn een aantal conclusies te trekken:

- De gemeente Beek telde op 31 december 2017, 314 inwoners met een bijstandsuitkering, oftewel 3 procent van het aantal inwoners dat tot de potentiële beroepsbevolking behoort.

- Dit percentage is lager dan het percentage in de bijbehorende COROP-regio Zuid-Limburg (4,9\%), maar min of meer gelijk aan het percentage voor de provincie Limburg als geheel $(4,1 \%)$.

- Zowel in de gemeente Beek als in de provincie Limburg als geheel is het percentage inwoners met een bijstandsuitkering min of meer gelijk aan het landelijk gemiddelde (4,2\%).

- Van de inwoners met een bijstandsuitkering, woonachtig in de gemeente Beek, werkt 11,1 procent. Dit is hoger dan het percentage in de COROP-regio Zuid-Limburg (8,9\%), min of meer gelijk aan het percentage voor Limburg als geheel (10,3\%) en gelijk aan het landelijk percentage $(11,1 \%)$.
Figuur 5 geeft voor iedere Limburgse gemeente het percentage inwoners weer dat een bijstandsuitkering ontvangt.

Uit Figuur 5 valt het volgende af te leiden:

- Het percentage inwoners met een bijstandsuitkering verschilt aanzienlijk tussen de Limburgse gemeentes.

- De gemeente Beek staat op de $20^{\mathrm{e}}$ plek in Limburg wat betreft het percentage inwoners met een bijstandsuitkering (gesorteerd van laag naar hoog).

Er is voor de gemeente Beek geen data op wijkniveau beschikbaar met betrekking tot het percentage mensen met een bijstandsuitkering. 


\section{Omvang risicogroepen in de Limburgse gemeente}

Beek

FIGUUR 5.

Percentage inwoners met een bijstandsuitkering naar Limburgse gemeente

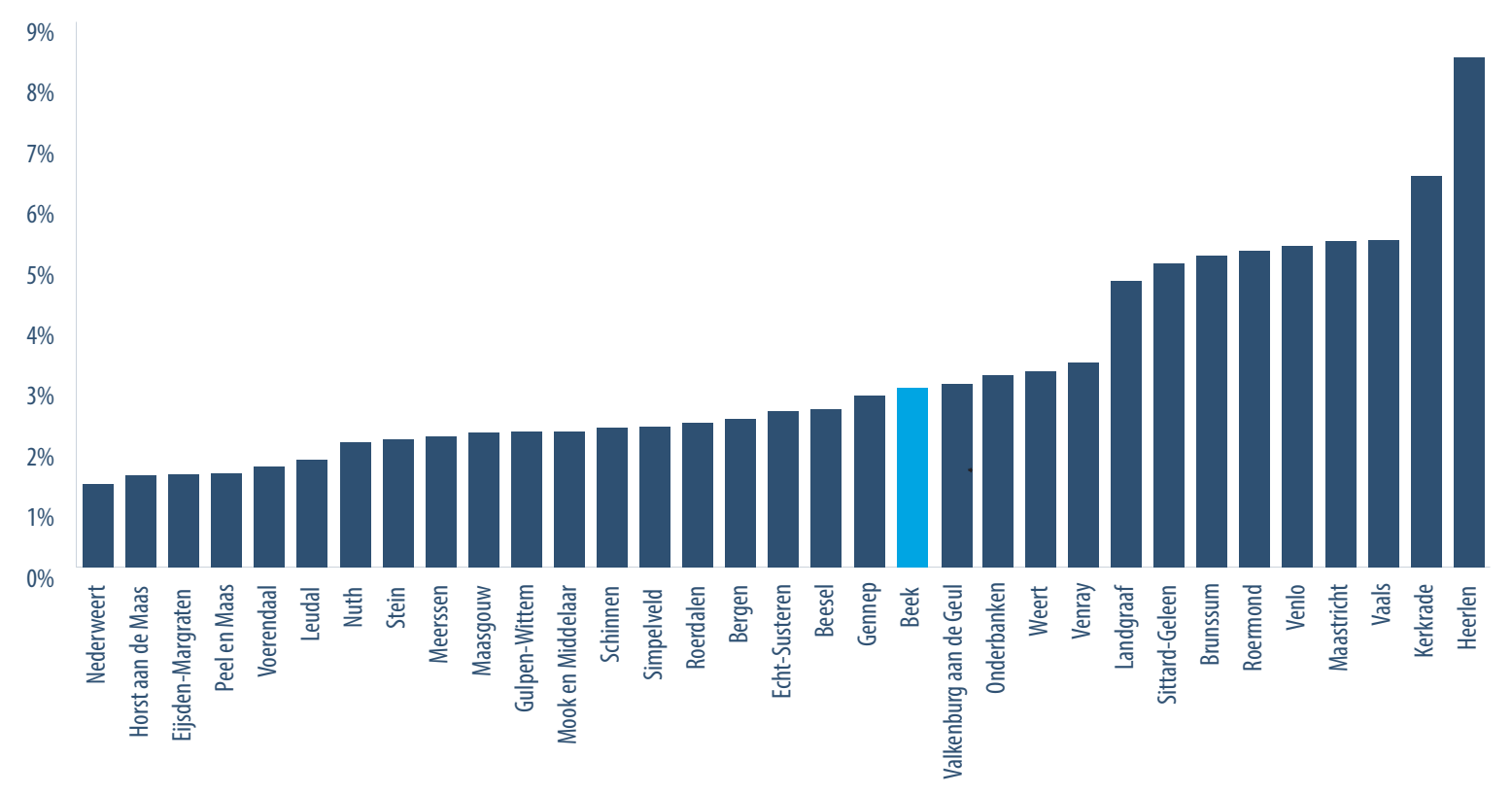

Bron: ROA, berekeningen op basis van microdata van het CBS 


\section{Factsheet}

ROA-F-2019/3 - Beek

\section{Inactieve inwoners die geen uitkering ontvangen of initieel onderwijs volgen}

TABEL 4.

Overzicht van de absolute en relatieve omvang van inactieve inwoners zonder uitkering

\begin{tabular}{|l|r|r|r|} 
& Aantal inactieve inwoners & Aantal inwoners behorend tot de potentiële & Percentage inactieve inwoners \\
beroepsbevolking & 10.594 & $6,9 \%$ \\
\hline Gemeente Beek & 730 & 187.721 & $6,4 \%$ \\
\hline Noord-Limburg & 11.934 & 157.217 & $7 \%$ \\
\hline Midden-Limburg & 10.976 & 395.604 & $8,3 \%$ \\
\hline Zuid-Limburg & 32.869 & 740.542 & $7,5 \%$ \\
\hline Limburg totaal & 55.779 & 11.460 .361 & $7,1 \%$ \\
\hline Nederland totaal & 813.554 & & \\
\hline
\end{tabular}

Bron: ROA, berekeningen op basis van microdata van het CBS

Tabel 4 geeft een overzicht van de omvang van het aantal inactieve personen in de gemeente Beek. Zoals eerder aangegeven gaat hierbij om personen die inactief zijn op de arbeidsmarkt zonder dat zij onderwijs volgen of een arbeidsongeschiktheids- werkloosheidsof bijstandsuitkering ontvangen. Personen die de AOW-gerechtigde leeftijd reeds hebben bereikt en personen die een pensioenuitkering ontvangen worden niet als inactief beschouwd.

Om de cijfers voor Beek in context te plaatsen worden ze ook hier weer vergeleken met de cijfers voor de provincie Limburg als geheel en de drie onderliggende COROP-gebieden Noord-, Midden- en Zuid-Limburg.

Uit Tabel 4 zijn een aantal conclusies te trekken:

- De gemeente Beek telde op 31 december 2017, 730 inactieve inwoners, oftewel 6,9 procent van het aantal inwoners dat tot de potentiële beroepsbevolking behoort.

- Dit percentage is min of meer gelijk aan het percentage in de bijbehorende COROP-regio ZuidLimburg $(8,3 \%)$ en tevens min of meer gelijk aan het percentage voor de provincie Limburg als geheel $(7,5 \%)$.

- Zowel in de gemeente Beek als in de provincie Limburg als geheel is het percentage inactieve inwoners min of meer gelijk aan het landelijk gemiddelde $(7,1 \%)$.
Figuur 6 geeft voor iedere Limburgse gemeente het percentage inactieve inwoners weer. Uit de figuur valt het volgende af te leiden:

Op basis van Figuur 6 kunnen we de volgende conclusies trekken:

- Het percentage inactieve inwoners verschilt aanzienlijk tussen de Limburgse gemeentes.

- De gemeente Beek staat op de $15^{\mathrm{e}}$ plek in Limburg wat betreft het percentage inactieve inwoners (gesorteerd van laag naar hoog).

Figuur 7 geeft de spreiding binnen de gemeente Beek weer in het percentage inactieve inwoners.

- In de wijk Beek-Spaubeek is het percentage inactieve personen 6,9 procent.

- In de wijk Beek-Zuid is het percentage inactieve personen 7,1 procent. 


\section{Omvang risicogroepen in de Limburgse gemeente}

Beek

FIGUUR 6.

Percentage inactieve inwoners zonder uitkering naar Limburgse gemeente

$14 \%$

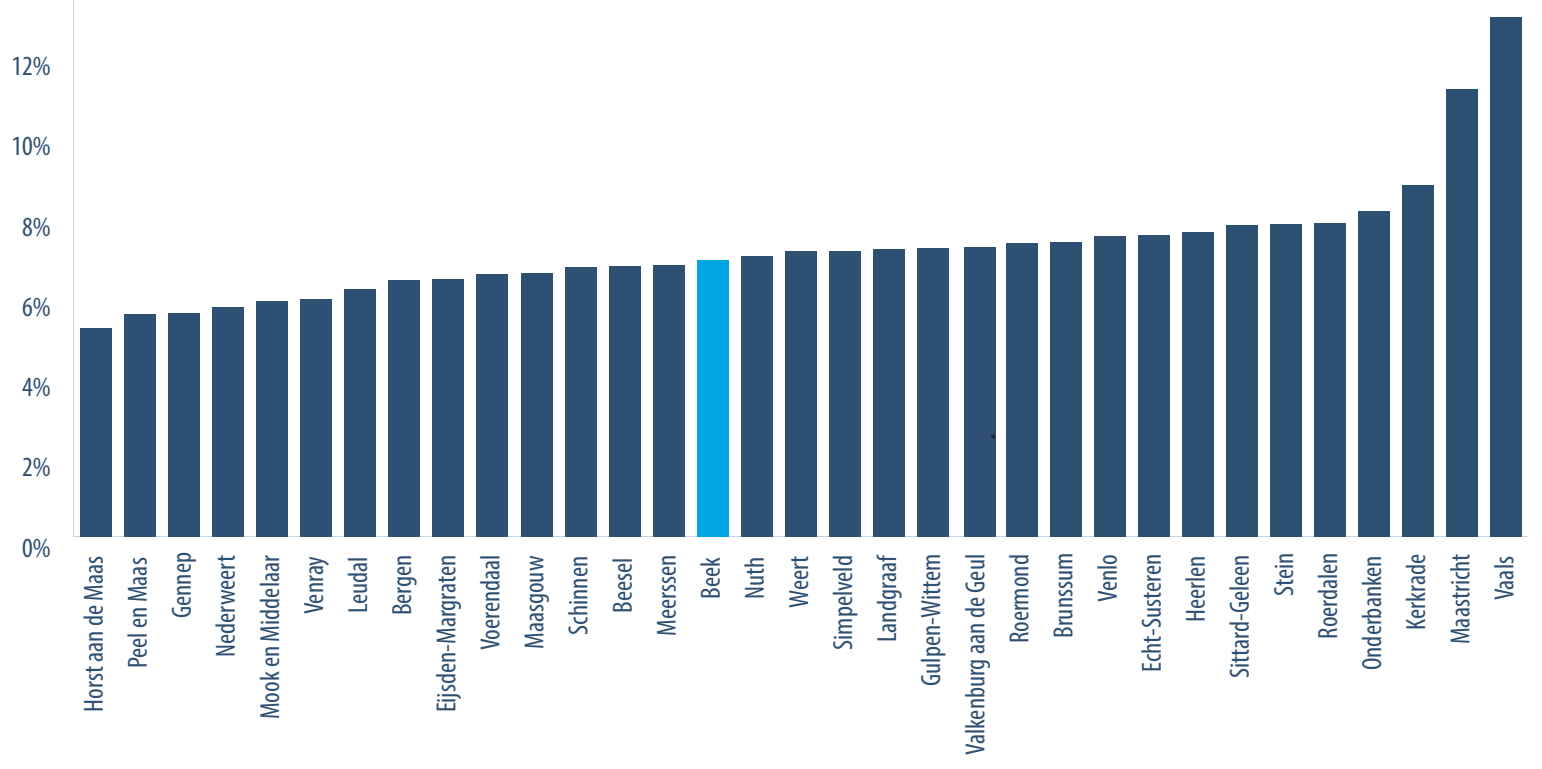

Bron: ROA, berekeningen op basis van microdata van het CBS

FIGUUR 7.

Percentage inactieve inwoners zonder uitkering naar wijk

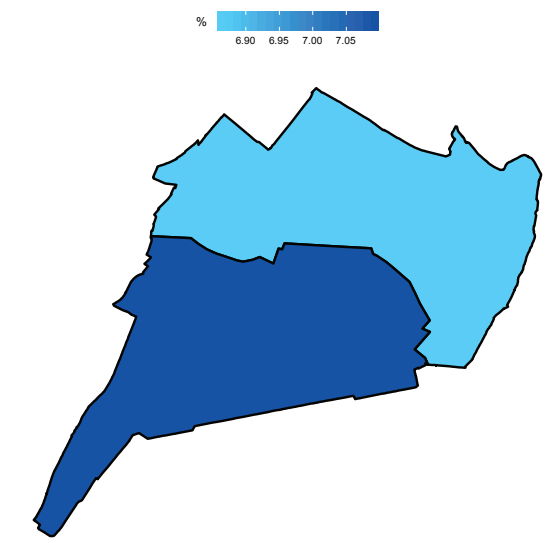

Bronnen: ROA, berekeningen op basis van microdata van het CBS; Kadaster/CBS, Wijk- en buurtkaart 2017 


\section{Factsheet}

ROA-F-2019/3 - Beek

\section{Totale groep inwoners in een risicopositie}

TABEL 5.

Overzicht van de absolute en relatieve omvang van inwoners in een risicopositie

\begin{tabular}{|l|r|r|r|r|}
\hline & Aantal inwoners in een risicopositie & $\begin{array}{r}\text { Aantal inwoners behorend tot de } \\
\text { potentiele beroepsbevolking }\end{array}$ & $\begin{array}{r}\text { Percentage inwoners in een risicopositie } \\
\text { Percentage werkenden } \\
\text { onder inwoners in een } \\
\text { risicopositie }\end{array}$ \\
\hline Gemeente Beek & 2.077 & 10.594 & $19,6 \%$ & $15,3 \%$ \\
\hline Noord-Limburg & 35.702 & 187.721 & $19 \%$ & $17,1 \%$ \\
\hline Midden-Limburg & 31.996 & 157.217 & $20,4 \%$ & $14,8 \%$ \\
\hline Zuid-Limburg & 100.154 & 395.604 & $25,3 \%$ & $12,3 \%$ \\
\hline Limburg totaal & 167.852 & 740.542 & $22,7 \%$ & $13,8 \%$ \\
\hline Nederland totaal & 2.286 .183 & 11.460 .361 & $19,9 \%$ & $13,9 \%$ \\
\hline
\end{tabular}

Bron: ROA, berekeningen op basis van microdata van het CBS

Hierboven werden achtereenvolgens telkens één van de vier risicogroep geïsoleerd in kaart gebracht. Tabel 5 geeft een overzicht van de totale groep mensen in een risicopositie voor de gemeente Beek. Het betreft hier personen die ófwel één of meerdere van de onderscheiden uitkeringstypes ontvangen óf inactief zijn op de arbeidsmarkt. Omdat individuen tegelijkertijd meerdere uitkeringen kunnen ontvangen wijkt de totale groep inwoners in een risicopositie af van de optelsom van de afzonderlijke uitkeringsontvangers en inactieven. Om de cijfers voor Beek in context te plaatsen worden ze uiteraard weer vergeleken met cijfers voor de provincie Limburg als geheel en de drie onderliggende COROPregio's Noord, Midden en Zuid-Limburg.

Uit Tabel 5 zijn een aantal conclusies te trekken:

- In totaal bevinden 2.077 personen, oftewel 19,6 procent van de 15 - tot en met 67-jarige inwoners, in de gemeente Beek zich in een risicopositie.

- Het percentage inwoners in een risicopositie is hiermee lager dan dat van de bijbehorende COROPregio Zuid-Limburg $(25,3 \%)$, lager dan het percentage in de provincie Limburg als geheel $(22,7 \%)$ en min of meer gelijk aan het landelijke percentage (19,9\%).

- Van de inwoners behorend tot een risicogroep, woonachtig in de gemeente Beek, werkt 15,3 procent. Dit is hoger dan het percentage in de COROP-regio Zuid-Limburg (12,3\%), min of meer gelijk aan het percentage voor Limburg als geheel $(13,8 \%)$ en min of meer gelijk aan het landelijk percentage (13,9\%).
Figuur 8 geeft voor iedere Limburgse gemeente het percentage inwoners in een risicopositie weer. Uit de figuur valt het volgende af te leiden:

- Het percentage inwoners in een risicopositie verschilt aanzienlijk tussen de Limburgse gemeentes.

- De gemeente Beek staat op de 13e plek in Limburg wat betreft het percentage inwoners in een risicopositie (gesorteerd van laag naar hoog).

Figuur 9 geeft de spreiding binnen de gemeente Beek weer in het percentage inwoners in een risicopositie.

Op basis van Figuur 9 kunnen we de volgende conclusies trekken:

- In de wijk Beek-Spaubeek is het percentage personen in een risicopositie 20 procent.

- In de wijk Beek-Zuid is het percentage personen in een risicopositie 16,4 procent. 


\section{Omvang risicogroepen in de Limburgse gemeente}

Beek

FIGUUR 8.

Percentage inwoners in een risicopositie naar Limburgse gemeente

$35 \%$

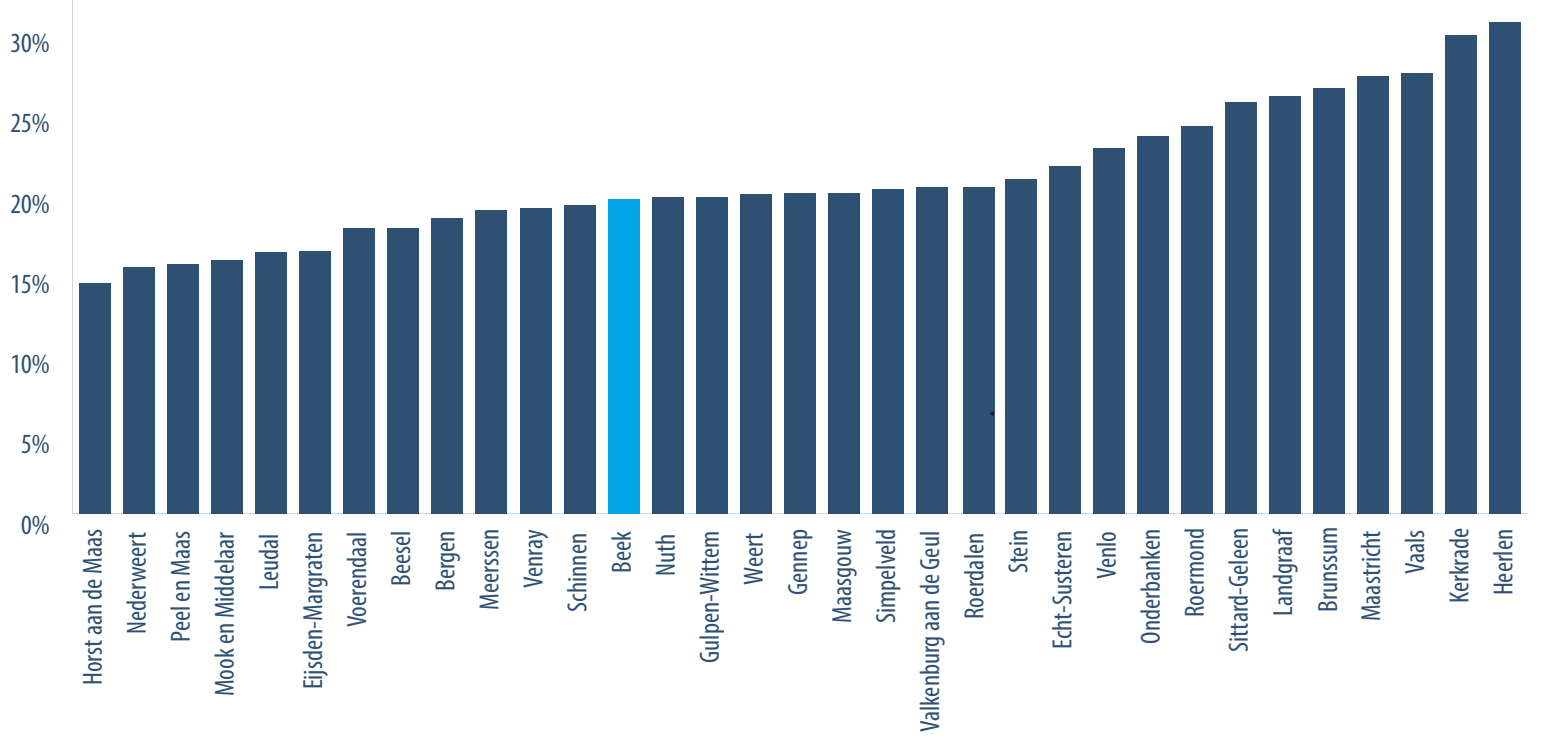

Bron: ROA, berekeningen op basis van microdata van het CBS

FIGUUR 9.

Percentage inwoners in een risicopositie naar wijk

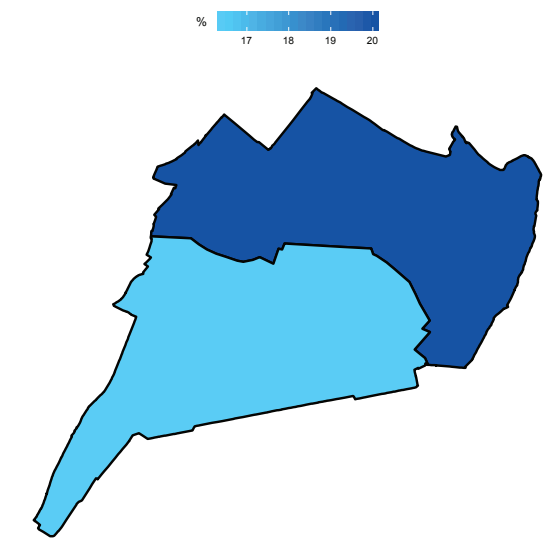

Bronnen: ROA, berekeningen op basis van microdata van het CBS; Kadaster/CBS, Wijk- en buurtkaart 2017 
Factsheet ROA-F-2019/3 - Beek 


\section{S4LIMBURG}

Deze factsheet is een onderdeel van het meerjarenprogramma 4 Limburg dat een bijdrage wil leveren om de Limburgse samenleving meer duurzaam, vitaal en inclusief te maken. Het doel van dit programma is om, in nauwe samenwerking met de Universiteit Maastricht, Provincie Limburg en ketenpartners zoals gemeenten, UWV en bedrijfsleven, via een trendbreuk de arbeidsparticipatie én de vitaliteit in Limburg naar een hoger niveau te tillen. Er zijn in Limburg veel mensen zonder werk onder de potentiële beroepsbevolking. Inzicht in de omvang en complexiteit van de groep uitkeringsontvangers en de groep inactieven die geen uitkering ontvangen en geen initieel onderwijs volgen is nodig alvorens initiatieven kunnen zorgen voor een inclusieve arbeidsmarkt waar iedereen in kan participeren. Deze factsheet heeft als doel de omvang van deze risicogroepen in de gemeente Beek in kaart te brengen. Mogelijk zal later dit jaar de complexiteit van de problematiek van degenen die tot een risicogroep behoren in een factsheet voor de Provincie Limburg in kaart gebracht worden.

\section{Colofon}

๑) Researchcentrum voor Onderwijs en Arbeidsmarkt Niets uit deze uitgave mag op enige manier worden verveelvoudigd zonder voorafgaande schriftelijke toestemming van de directeur van het ROA.

Researchcentrum voor Onderwijs en Arbeidsmarkt

Maastricht University

School of Business and Economics

secretary-roa-sbe@maastrichtuniversity.n

www.roa.nl

\section{Vormgeving}

ROA secretariaat, Maastricht 